\title{
The Development of Digital Comic Media to Overcome Students' Academic Procrastination
}

\author{
Ella Lukitasari* \\ Postgraduate Guidance and Counseling Program \\ Universitas Negeri Yogyakarta \\ Yogyakarta, Indonesia \\ ellalukitasari.2018@student.uny.ac.id, \\ ellalukitasr@gmail.com*
}

\author{
Budi Astuti \\ Department of Educational and Guidance Psychology \\ Universitas Negeri Yogyakarta \\ Yogyakarta, Indonesia \\ budi_astuti@uny.ac.id
}

\begin{abstract}
This study aims to determine the effectiveness and feasibility of developing digital comic media to overcome academic procrastination for students. This research uses quantitative and qualitative methods which carried out through research and development approaches. The activities carried out in this study involve two steps; the data was collected with an inventory of academic procrastination criteria and student academic procrastination scales. The quantitative data were analyzed by applying descriptive statistical techniques and inferential statistical techniques by $t$ test. Qualitative data were analyzed by applying qualitative descriptive analysis techniques. The results showed that the development of digital comic media was empirically proven effective in overcoming students' academic procrastination. This is supported by the increasing of students' awareness in overcoming academic procrastination in the experimental class included in the high category with a gain score of 0.70 . Based on these results it can be seen that the digital comic produced is feasible and effectively used as a media for guidance and counseling services in schools.
\end{abstract}

Keywords - comic, digital, procrastination, academic, students

\section{INTRODUCTION}

Nowadays, in education world the workers such as teachers are required to master and utilize technology in the learning process, including the teacher of guidance and counseling in their services. Based on one of the principles in guidance and counseling, namely the present principle, it is stated that guidance and counseling teachers are demanded to have innovation in delivering the service. Media can be an interesting learning tool for teachers to deliver the materials to students at school. Media is defined as technology that supports and expands human communication. Information represents a form of unidirectional communication. Therefore, information services are also understood as media services [1]. One innovation that could be done is the use of media in services.

A student will be more motivated in learning if supported by a teacher who uses a lot of variations in delivering the material and other supporting infrastructures, such as interesting learning media. There are several criteria that need to be considered in choosing media, namely: 1) In accordance with the objectives to be achieved. The media are chosen based on predetermined learning objectives and in general, referring to one or a combination of two or three cognitive domains. 2) Appropriate to support the content of lessons including facts, concepts, principles, or generalizations. Different media, such as films and graphics, require different mental skills to understand them. 3) Practical, flexible, and enduring. If there is no time, funds or other resources available to produce, it does not need to be forced [2]. Media is a manifestation of the existence of various types of components in the student environment that can stimulate students to learn [3]. Based on the readiness its existence, media is grouped into two types, namely the finished media because it is a trade commodity and there is a wide market in a ready-made state, and the design media because it needs to be specifically designed and prepared for specific learning purposes [4]. Many media can be used in the implementation of guidance and counseling services, one of which is the use of digital comic media.

Comics are a sequence of images arranged according to the purpose and philosophy of the creator so that the message of the story is conveyed, comics tend to be given the lettering that is adjustable according to students' needs [5]. The task related students' development, especially adolescents, is including cognitive, such as increased abstract, idealistic, and logical thinking abilities. Meanwhile, socio-emotional changes experienced by adolescents such as independence, the desire to spend more time with peers, and the conflict with parents began to emerge [6]. Based on this, it can be seen that the needs and thoughts of students change according to the development of their age.

Socio-emotional changes in students can affect their daily behavior. The progress of cognitive development to improve the quality of interpersonal relationships because it makes teens are able to better understand the desires, needs, feelings and motivations of others [7]. That is why it is not surprising that, increasing complex thoughts, emotions and identities in adolescence, social relationships are becoming increasingly complex. Improving the quality of education is certainly supported by students' learning outcomes. However, to achieve maximum learning achievement many factors affect both internally and externally. One internal factor is the habit of delaying assignments or procrastination by students.

The habit of procrastinating is usually called procrastination, because the task is part of academic activity, 
it can be called academic procrastination. Procrastination was done repeatedly because other not related activities was prioritize first [8]. Losses resulting from procrastination behavior tasks not completed, or completed but not perfect, because of being haunted by a deadline [9]. Causing anxiety throughout the time the task is carried out, resulting the high number of errors due to very limited time.

Middle School students at their stage of development is full of emotion that arises because of a conflict of values. During this period adolescents were still unable to master their physical and psychological functions. Adolescence is an important period of life, a transitional period, a period of change, a period of problematic age, a period in which individuals look for identity, scary age (dreaded), a period of unrealism and a threshold towards maturity [10]. Adolescence in terms of human life span is a transition from childhood to adulthood. Some of the characteristics of adolescents are no longer the characteristics of childhood, but also have not shown the characteristics as an adult [11].

Sample of 580 individuals (329 female students and 251 male students). They have observed male students intending to procrastinate more than female students. According to the next hypothesis, procrastination will occur higher in students aged less than 20 years old than above 20 years old [12]. Uncovering the age factor in academic procrastination is a significant difference between age groups. Younger individuals tend to procrastinate more than older individuals. Available literature shows various causes of procrastination among individuals of different age groups [13].

The tasks of adolescent development is achieving emotional independence from parents or figures who have authority. So that in carrying out its developmental tasks the role of parents and those around them is needed especially in the academic field to improve their learning achievement [14]. The task and role of the teacher is to encourage students to learn in order to construct their own knowledge through various activities such as problem solving and communication [15]. This encourages educators to innovate more in the learning system. One of them is developing digital comic media as a guidance and counseling service media.

\section{METHODS}

The Research and Development (R\&D) theory was used in this research [16]. The product research is the development of digital comic media to overcome students' academic procrastination. The data were collected through an inventory of academic procrastination issues and a student academic procrastination assessment scale. The descriptive analysis was used to analyze data from the results of preliminary studies, namely qualitative and quantitative. Meanwhile, researchers used the f-test (test of two different averages) statistical analysis techniques through a calculation process using SPSS 17.00 for Windows. Qualitative data obtained from the input or advice of media and material experts are collected to improve the development of comic media products.
The data analysis technique used in this research and development is quantitative descriptive. Quantitative data analysis is performed after all data from respondents or data sources have been collected statistically [17].

Furthermore, here are the steps of data analysis for comic feasibility:

1. Tabulate all the collected data

2. Count the average percentage:

Information:

$\mathrm{p}=$ average score percentage

$\mathrm{f}=$ frequency

$\mathrm{N}=$ Number of Cases

(the amount of percentage/ individuals)

In order to make it easier the application of the formula above, $\mathrm{f}$ refers to the sum of the score and $\mathrm{N}$ refers to the multiplication of the highest score with the amount of questions.

3. Change the average percentage score obtained into a value by referring to the change of the score to the four scale according to the Technical Guidelines for Making Affective Assessment in High School.

In this research, the developed comic media is feasible if the results of data analysis meet the conversion of "feasible" or get a minimum percentage score of $65 \%$ with the category of "good". So, if the assessment of material experts, media experts, guidance and counseling practitioners and students gives the final result of at least $65 \%$, then the comic media is able to overcome academic procrastination. Meaning that it is considered suitable for use as a media for guidance and counseling in schools.

Data Analysis of the Effectiveness of the Comic Media

Data about academic procrastination in students was obtained through the initial scale (before the comics are distributed) and the final scale (after the comics are distributed). The results of the academic procrastination assessment scale that was carried out on $23 \mathrm{X}$ graders high school students were then analyzed using the normalized gain or gain score technique. Data analysis using the gain technique aims to see the effectiveness or the level of student academic procrastination arising from the use of comic media as a guidance and learning counseling service. The calculation steps with the gain technique are as follows:

1. Calculate the average score of students both pre-test scores and post-test scores

2. Calculate the gain $\langle\mathrm{g}\rangle$ with formula:

$\langle\mathrm{g}\rangle$

where:

$<\mathrm{g}>$ = gain score

$\mathrm{Sf}=$ post-test average score

$\mathrm{Si}=$ pre-test average score

3. Determine the criteria of the comic media effectiveness:

Table 1. Determine the criteria of the comic media effectiveness

\begin{tabular}{|c|c|}
\hline Score & Category \\
\hline $\mathrm{g} \geq 0,7$ & High \\
\hline $0,7>\mathrm{g} \geq 0,3$ & Medium \\
\hline $\mathrm{G}<0,3$ & Low \\
\hline
\end{tabular}


Development of comic media is effective if the results of data analysis get a minimum value of 0.7 in the "high" category. So, if a student rating scale distributed to a large group gives a minimum gain of 0.4 , then the comic media is able to overcome academic procrastination. Meaning that it is considered effective as a medium for guidance and counseling in schools. Data obtained from the research development of comics about academic procrastination include: 1) product assessment data, 2) limited trial data and 3) field trial data.

\section{RESULT AND DISCUSSION}

Result

Data from the products include the data from material experts, media experts, guidance and counseling teachers. The data is in the form of assessment, evaluation and advice on aspects of comic anatomy, design and color, overall appearance, material appropriateness, material accuracy, and linguistic aspects. The assessment results are in the form of scores which are then converted into four scale values.

Based on the results of quantitative data that have been obtained, it can be concluded that the assessment of media experts based on the conversion of the four scale in appendix 15 showed the results of a percentage of $78.95 \%$ with a value of "B" and included in the criteria of "good", the expert judgment of the material based on a four scale conversion shows the results a percentage of $73.75 \%$ with a value of "B" and included in the criteria of "good", expert judgment based on the conversion of the scale of four shows the results of a percentage of $85.81 \%$ with a value of "A" and included in the criteria of "very good", student responses to comics based on the conversion of the four scale to show the results of a percentage of $85.81 \%$ with a value of "B" and included in the criteria of "good", data on the results of the scale of students in the initial and final field trial groups can be seen in the following table:

Table 2. Pretest and Posttest Academic Procrastination Scale Test Data

\begin{tabular}{|c|c|c|}
\hline Score & Pretest & Posttest \\
\hline Highest & 71 & 95 \\
\hline Lowest & 60 & 85 \\
\hline Average & 65,74 & 89,96 \\
\hline Gain Score & \multicolumn{2}{|c|}{0,70} \\
\hline
\end{tabular}

Based on the table 2, it can be concluded that the achievement of increased awareness about academic procrastination has been experienced by students. Academic procrastination scale analysis results obtained gain score $\langle\mathrm{g}\rangle=0.70$ indicates that the increase is "high".

\section{Discussion}

Based on the research analysis and review of the results above, it can be concluded that digital comic media can be an effective media as a guidance and counseling service. In fact, students in schools have a high tendency to do academic procrastination. Students at school almost have to do or complete their academic assignments every time.
This is also what can trigger the emergence of academic procrastination. So, it can be assumed that students have a high risk to procrastinate their academic tasks.

Procrastination dominates all fields of behavior and actions but the most common form is academic procrastination that occurs in academic settings [19]. Procrastination is a personality weak point and leads to low self-confidence [20]. Procrastination is a voluntary delay carried out by an individual on his job / work even though he knows that this will have a bad impact on the future [21]. Report studies that show a strong negative relationship between consciousness and procrastination, and also between age and procrastination [22]. As age and maturity getting older, conscience increases and neurobiological development reaches its completion; while on the other hand, young people lack self-control and show low of awareness because they still develop their prefrontal cortex.

Three main dimensions that influence procrastination including intrapersonal factors, situational factors, and task characteristics [23]. The first dimension is related to one's dimension of personality. Numerous studies have shown that neuroticism is positively associated with procrastination; whereas, awareness is negatively related to procrastination. The second main dimension is based on situational factors which indicate that delaying behavior may be caused by a number of situations outside the person's control situation such as poor health or family problems that cause people who don't like to procrastinate delaying work. The third dimension relates to task characteristics, for example, employees can show delays when they face tasks that are impossible to achieve or do not have a clear deadline to complete. Various studies have linked procrastination with negative physical and mental health outcomes and also with greater stress vulnerability. Procrastination is a pattern of behavior that is mediated by behavioral pathways such that poor health of procrastinators is a result of stress caused by procrastination, ineffective use of coping styles, and also delaying important health behaviors [24].

Procrastinators like to avoid assignments and commitments that they consider unpleasant and also do not accept being blamed for being late by justifying them on the grounds [25]. Procrastinators like to hold unrealistic expectations, less effective time management, and organizational skills that cause anxiety and fear about the task at hand, leading to negative beliefs about their personal and professional abilities. Overall, procrastination is seen as a common, social, academic, professional, and marriage problem for people. Procrastination may succeed in certain circumstances where the time pressure created by delaying assignments can be actualized as a challenge of energizing performance while also reducing boredom [26]. Students can also use procrastination as a way of balancing social and academic activities, adjusting their study schedules to work in study groups, or creating time pressure for motivational purposes.

The conclusion of the explanation above is that procrastination is a delay that is done intentionally and 
repeatedly, by carrying out other activities that are not needed in carrying out important tasks. So, someone is said to procrastinate if he delays important work without a logical reason, even though he can do it on time inline with the plans that have been made previously. As a typical procrastination behavior, procrastination is usually mostly done on certain types of work or on all matters related to individual tasks as procrastinators. Procrastination is related to psychological distress and causes psychological distress, however it is still not considered a matter of mental condition [27].

Based on the academic procrastination problem, learning in schools will be even better if it is made to be more interesting and enjoyable. Effective learning activities are processes in completing learning tasks and achieving learning goals in the expected time, so it can be said that effective learning is oriented towards the success of achieving learning objectives [28]. The components needed to achieve the success of the learning process, including the existence of learning objectives, learning materials, learning media, learning strategies, and learning evaluation [29]. The use of digital comics can improve students' understanding of the content of the lesson, the desire of students to explore and improve critical thinking skills [30]. Digital comics are simple comics that are presented in certain electronic media.

Digital comics are also defined as comics published / presented on websites, webcomics, online comics, or internet comics [31]. Combining words, images, gestures and audio really provides an interesting experience for students [32]. A person can learn better by combining pictures and writing [33]. Comics as a learning medium are tools that function to convey instructional messages that can function well as visual communication of learning media, where the learning context refers to the process of communication between students and learning resources [34].

The advantages of comics that are very popular with students can be utilized in the learning process. The use of comics in the learning process contributes greatly to students' long-term memory [35]. Comics are a popular art form among children and are a potential medium for educational and communication activities [36]. The use of digital comic / digital storytelling can develop creativity, innovation, motivation, learning activities, and valuable learning experiences for students [37]. Based on the statements above it can be concluded that the use of digital comic media can increase student interest and involvement in following the learning process and make the learning activities more enjoyable.

\section{CONCLUSION}

Digital comic media to overcome students' academic procrastination is feasible to be developed. Based on the results of validation from media experts, material experts and guidance and counseling teachers, all aspects of comics including aspects of comic anatomy, design and color, overall appearance, material appropriateness, material accuracy, material present, language and academic procrastination obtain the average percentage of $79.94 \%$ included in the "good" category. This proves that the product development of comic media to overcome academic procrastination in students is feasible and appropriate to be used in counseling and guidance services in the classroom.

The developed comic media has proven to be effective in raising awareness to overcome students' academic procrastination. The effectiveness of comic media can be seen from the data obtained through the academic procrastination scale sheet in the experimental class. The results of the analysis of the scale of academic procrastination in the class after using comic media obtained a gain score $\langle\mathrm{g}\rangle=0,70$. This shows that an increase in awareness is in "high" category.

\section{ACKNOWLEDGEMENT}

The deepest gratitude was delivered to the supervisor and friends who have facilitated and helped in writing this article.

\section{REFERENCES}

[1] Gidio, Capretz, Meadows \& Gr. (2013). Media Usage Survey: How Engineering Instructors and Students Use Media. Proc. 2013 Canadian Engineering Education Association (CEEA13) Conf. Electrical and Computer Engineering Publications. 21. https://ir.lib.uwo.ca/electricalpub/21

[2] Kustandi, C. \& Sutjipto, B. (2013). Media Pembelajaran; Manual dan Digital. Bogor: Ghalia Indonesia

[3] Dina Indriana. (2011). Ragam Alat Bantu Media Pengajaran. Yogyakarta: DIVA Press

[4] Sadiman, A. S dkk. (2012). Media Pendidikan. Jakarta: PT. Raja Grafindo Persada

[5] Gumelar, M.S. (2011). Comic making : cara membuat komik. Jakarta: Indeks

[6] John W. Santrock (2007). Perkembangan Anak. Jilid 1 Edisi kesebelas. Jakarta : PT. Erlangga

[7] Oswalt, A. (2010). Developmental Psychology: A Lifespan Approach. (translate by Istiwidayanti). Jakarta: Erlangga Gunarsa

[8] M. N. Ghufron \& Rini Risnawati S. (2011). Teori - teori psikologi. Yogyakarta: Ar-Ruz Media

[9] Solomon and Ruthblum. (1984). Academic procrastination: frequency and cognitive behavioral correlates. Journal of Counseling Psychology. Vol. 31, 503-509

[10] Krori Deb. (2011). Developmental psychology, Homeopathic Journal :: Volume:4, Issue: 3, Jan, 2011. http://www.homeorizon.com/homeopathic articles/psychology/developmental-psychology

[11] Rita Eka Izzaty, dkk. (2008). Perkembangan peserta didik. Yogyakarta: UNY Press

[12] Balkis,M. \& Duru, E.(2009). Prevalence of Academic procrastination behavior among preservice teachers, and its relationship with demographic and individual preference. Journal of theory and practice in education $5(1), 18-32$

[13] Ozer, B., Demir, A., \& Ferrari, J. (2009). Exploring Academic Procrastination Among Turkish Students: Possible Gender Differences in Prevalence and Reasons. Journal of Social Psychology, 149(2), 241-257

[14] Yudrik Jahja. (2013). Psikologi perkembangan. Jakarta: Kencana Prenamedia Group

[15] Kusnaeni \& Heri Retnawati. (2013). Problem Posing dalam Setting Kooperatif Tipe TAI Ditinjau dari Kemampuan Komunikasi dan Pemecahan Masalah. PYTHAGORAS: Jurnal Pendidikan 
Matematika Volume $8-$ Nomor 1, Juni 2013, (33-43) http://journal.uny.ac.id/index.php/pythagoras

[16] Borg, W.R. \& Gall, M.D. (2007). Educational Research: An Introduction Eight Edition. New. York \& London: Longman

[17] Sugiyono. (2015). Metode penelitian \& pengembangan : Research and Development. Bandung: Penerbit Alfabeta

[18] Hake, R. R. (1998), Interactive-Engagement Vs Traditional Methods: A SixThousand-Student Survey of Mechanics Test Data for Introductory Physics Courses, American Journal of Physics, 13 (1). 1 23

[19] Khan, M.J, Arif, H., Noor, S.S., Muneer, S. (2014). Academic Procrastination among Male and Female University and College Students. FWU Journal of Social Sciences, Winter 2014, Vol. 8, No.2, 65-70 65

[20] Firouzeh. S. \& Jalil. J. F., (2011). The Effects of Coping Styles and Gender on Academic Procrastination among University Students. Journal of Basic and Applied Scientific Research. 1(12)2987 - 2993

[21] Steel, P. (2010). Arousal, avoidant and decisional Procrastinators: do they exist? Personality and Individual Differences, 48, 926-934

22] Steel, P., \& Ferrari, J. (2013). Sex, Education and Procrastination: An Epidemiological Study of Procrastinators' Characteristics from a Global Sample. European Journal of Personality, 27(1), 51-58. http://dx.doi.org/10.1002/per.1851

[23] Gupta, R., Hershey, D., \& Gaur, J. (2012). Time Perspective and Procrastination in the Workplace: An Empirical Investigation. Current Psychology, 31(2), 195-211.

[24] Ferrari, J. R., \& Díaz-Morales, J. F. (2014). Procrastination and Mental Health Coping: A Brief Report Related to Students. Individual Differences Research, 12(1), 8-11.

[25] Alghamdi, N. G. \& Abbasi, I. S. (2015). The Prevalence, Predictors, Causes, Treatment, and Implications of Procrastination Behaviors in General, Academic, and Work Setting: International Journal of Psychological Studies; Vol. 7, No. 1; 2015

[26] Skowronski, M., \& Mirowska, A. (2013).A Manager's Guide to Workplace Procrastination. SAM Advanced Management Journal (07497075), 78(3), 4-27

[27] Rozental, A., \& Carlbring, P. (2013). Internet-Based Cognitive Behavior Therapy for Procrastination: Study Protocol for a Randomized Controlled Trial. Journal of Medical Internet Research, 15(11), 27
[28] Zheng, L., Yang, J., Cheng, W., \& Huang, R. 2013. Emerging Approaches For Supporting Easy, Engaged and Effective Collaborative Learning. Journal of King Saud University-Computer and Information Sciences, 26, 11-16.

[29] Lamb, A., \& Johnson, L. 2009. Graphic Novels, Digital Comics, and Technology-Enhanced Learning: Part 1. Teacher Librarian, 36(5),7084

[30] Yang, Y.T.C. \& Wu, W.C.I. 2011. Digital Storytelling For Enhancing Student Academic Achievement, Critical Thinking, and Learning Motivation: A Year-Long Experimental Study. Computers and Education Journal, 59(12), 339-352

[31] Yunus, M., Salehi, H., Tarmizi, A., Idrus, SFS., Balaraman, S.S.A/P. 2010. Using Digital Comics in Teaching ESL Writing. Universiti Kebangsaan Malaysia

[32] Comer, K. 2015. Ilustrating Praxis: Comic Composition, Narrative Rhetoric and Critical Multiliteracies. Composition Studies, 43(1), 75 104

[33] Wankel, L.A. \& Blessinger, P. 2013. Inventive Approaches in Higher Education: An Introduction to Using Multimedia Technologies in Increasing Student Engagement and Retention Using Multimedia Technologies: Video Annotation, Multimedia Applications, Video Conferencing and Transmedia Storytelling. Cutting-edge Technologies in Higher Education, 6F, 3-16

[34] Vassilikopoulou M., Retalis S., Nezi M. \& Boloudakis, M. 2011. Pilot Use of Digital Educational Comics. Educational Media International Vol. 48, No. 2, June 2011, 115-126

[35] Negrete, A. 2013. Constructing a Comic to Communicate Scientific Information About Sustainable Development and Natural Resources in Mexico. Procedia-Social and Behavioral Sciences, 103(1), 200-209

[36] Tatalovic, M. 2009. Comics As Tools For Science Education and Communication: A Brief, Exploratory Study. Journal of Science Communication, 8(4), 1-17

[37] Azman, F.N., Zaibon, S.B., \& Shiratuddin, N. 2016. Pedagogical Analysis of Comic Authoring Systems for Educational Digital Storytelling. Journal of Theoretical and Applied Information Technology, 89(2), 461-46 